\title{
Pembentukan Rubamasusa (Rumah Baca Masyarakat Suku Sambori) Sebagai Upaya Mewujudkan Masyarakat Sadar Literasi
}

\author{
Nurhidayah $_{123}^{1}$, Roni Irawan ${ }^{2}$, Fatmah ${ }^{3}$ \\ Dosen STKIP Taman Siswa Bima \\ Email : nur930838@gmail.com
}

\begin{abstract}
Abstrak. Ruman baca di dalam masyarakat merupakan salah satu instrumen penting untuk menunjang kebutuhan masyarakat terhadap informasi dan pengetahuan. Kegiatan pengabdian ini bertujuan untuk merintis pembangunan RUBA MASUSA di dusun Lengge desa sambori. Gambaran situsi/ keadaan pendidikan di Sambori khususnya Dusun Lengge cukup kompleks, pada umumnya juga hampir sama dengan beberapa keadaan pendidikan di daerah- daerah terpencil Indonesia lainnya yaitu tingkat pendidikan dan ekonomi masyarakat yang masih rendah, yang dominan berpengaruh pada tingkat kesadaran akan pentingnya pendidikan. Rumah baca ini telah berisi koleksi buku yang dapat diakses oleh masyarakat sekitar dan telah diklasifikasikan berdasarkan subjeknya. Pembangunan Rumah baca tersebut telah mengatasi permasalahan keterbatasan akses dan penggunaan ruang baca sebelumnya dengan variasi koleksi buku bacaan dan ruang yang menarik. Program perintisan Rumah baca dengan target jangka panjang diharapkan dapat membuat masyarakat menjadi sadar pentingnya literasi dalam segala aspek kehidupan.
\end{abstract}

\section{Kata Kunci: RUBA MASUSA, Masyarakat Sadar Literasi}

\section{PENDAHULUAN}

Pengabdian kepada masyarakat merupakan salah satu bagian dari Tri Dharma Perguruan Tinggi, kegiatan pengabdian ini merupakan transformasi ilmu pengetahuan dalam kehidupan sosial budaya masyarakat. Kegiatan pengabdian dan kemitraan kepada masyarakat merupakan suatu wujud nyata yang dilakukan oleh perguruan tinggi kepada masyarakat untuk menghadapi berbagai problem dan kebutuhan sosial di era perkembangan industri 4.0. Untuk menjawab berbagai problem sosial yang berkembang di era 4.0, perguruan tinggi di tuntut untuk melaksanakan tri darma perguruan tinggi salah satunnya melaksanakan kegiatan pengabdian dan kemitraan kepada masyarakat.

Lokasi yang dipilih dalam melakukan pengabdian yang didanai oleh yayasan STKIP Taman Siswa Bima yaitu di dusun Lengge terletak di desa Sambori kecamatan Lambitu Kabupaten Bima NTB. Latar belakang melakukan pengabdian kemitraan masyarakat ini yaitu melihat kemampuan literasi masyarakat dusun Lengge yang sangat rendah, penyandang buta aksara masih banyak. Penyebabnya yaitu,letak geografis yang termasuk dalam remot area atau daerah 3T, jauh dari infrastruktur pendidikan, tingkat pendidikan dan ekonomi masyarakat yang rendah serta kesadaran pentingnya pendidikan sangat minim.

Adapun yang menjadi lokus dalam pengabdian ini adalah dusun Lengge desa Sambori. Untuk dusun Lengge didiami oleh sebanyak 954 jiwa yang terdiri dari 473 penduduk laki-laki dan 481 jiwa penduduk perempuan. Sementara penduduk dusun Lambitu sebanyak 832 jiwa penduduk yang terdiri dari 422 penduduk laki-laki dan 410 penduduk perempuan.Mayoritas penduduknya bermata pencaharian sebagai petani. Adapun yang menjadi komoditi utama masyarakat adalah padi, jagung dan bawang putih.

Desa Sambori terbilang masih sangat minim dari segi fasilitas pendidikan. Institusi pendidikan formal yang terdapat di desa Sambori yang tertinggi adalah tingkat Sekolah Dasar (SD) saja, yaitu Sekolah Dasar Negeri (SDN) Sambori dan Sekolah Dasar Negeri 
(SDN) Inpres Sambori, letak kedua sekolah jarak jauh dari perkampungan dusun Lengge. Selain itu ada lembaga pendidikan non formal yaitu 1 Taman Kana- kanak dan 1 Kelompok Bermain.

Anak- anak dari dusun Lengge seluruhnya sekolah di SDN Inpres Sambori, yaitu 107 anak dari 117 siswa. Sisanya 10 siswa dari dusun Lambitu. Anak- anak Sekolah Dasar dari dusun Lengge menempuh jarak ke sekolah sekitar $1 \mathrm{~km}$ dan menghabiskan waktu tempuh dengan berjalan kaki sekitar 30 menit. Sedangkan untuk tingkat pendidikan jenjang SMP dan SMA mereka harus sekolah di pusat kecamatan yang jaraknya lebih kurang $3 \mathrm{Km}$.

Gambaran situsi/ keadaan pendidikan di Sambori khususnya Dusun Lengge cukup kompleks, pada umumnya juga hampir sama dengan beberapa keadaan pendidikan di daerahdaerah terpencil Indonesia lainnya yaitu tingkat pendidikan dan ekonomi masyarakat yang masih rendah, yang dominan berpengaruh pada tingkat kesadaran akan pentingnya pendidikan. Tingkat pendidikan orangtua siswa dusun Lengge mayoritas tamatan SD, tamatan SMP 11 Orang dan tamatan SMA 3 Orang. Oleh karena demikian sebagian besar dari orang tua siswa masih banyak yang belum bisa baca tulis dengan lancar atau bisa disebut degan buta aksara.

Alternatif fasilitas pendidikan yang belum terjangkau seperti perpustaaan desa, dan kelompok belajar lainnya. Kemudian, jarak antara sekolah dengan perkampungan yang cukup jauh dengan medan tempuh yang sulit (tanjakan dan turunan tajam). Medan jalan dari dusun Lengge menuju sekolah, baru diaspal pada tahun 2018 akhir, yang sebelumnya hanya berbentuk jalan setapak dan bebatuan yang cukup licin pada musim hujan tiba. Jarak sekolah yang jauh ini menyebabkan sebagian anak- anak dusun Lengge khususnya di jenjang pendidikan Sekolah Dasar (SD) yang terkadang jarang masuk sekolah.

Musim hujan menjadi tantangan bagi anak- anak Lengge untuk pergi sekolah. Taruhan medan yang tambah sulit, pakaian dan buku yang terancam basah. Dan tidak jarang orang tua mereka lebih sering mengajak anakanaknya ikut pergi menginap di ladang beberapa hari dan bahkan minggu, karena mayoritas masyarakat dusun Lengge adalah petani. Sementara itu, bagi anak- anak yang tidak ikut orang tua berladang, tentu akan mengalami kesulitan dalam mempersiapkan keberangkatan mereka ke sekolah, karena pagipagi sekali anak- anak Lengge harus bangun dan menyiapkan makanan dan pakaian sekolah sendiri, dan akan menuju sekolah yang jaraknya $1 \mathrm{~km}$ dengan berjalan kaki sekitar 30 menit atau lebih. Sehingga hal ini menyebabkan mereka terlambat ke sekolah atau bahkan tidak berangat ke sekolah.

Dusun Lengge Desa Sambori termasuk dalam kawasan minim jaringan telepon dan internet. Sehingga masyarakat yang membutuhan akses daring akan kesulitan. Dan harus mencari lokasi- lokasi tertentu yang sekitar pemukiman untuk melakukan akses berbagai informasi. Hal ini tentu menjadi sebuah kendala tersendiri dalam pengembangan masyarakat dusun Lengge yang pada masa sekarang ini berbagai aspek kehidupan sudah tidak terlepas dari kemajuan teknologi dan informasi.

Kondisi perekoniman yang kurang baik dan kurangnya kesadaran masyarakat akan pentingnya pendidikan bagi anak menyebabkan anak-anak di dusun Lengge memiliki akses yang terbatas terhadap pendidikan. Mayoritas pendidikan anak di dusun Lengge adalah Sekolah Dasar (SD) , Sekolah Menengah Pertama (SMP) dan sebgian masih melanjutkan Sekolah Menengah Atas (SMA). Pada umumnya orang tua tidak memiliki keinginan untuk menyekolahkan anaknya sampai jenjang selanjutnya tersebut sehingga selepas SMP dan SMA anak-anak di desa tersebut memutuskan untuk bekerja menjadi TKI dan TKW di negara tetangga dan sebagian banyak yang memutuskan menikah dini.

Hal tersebut merupakan salah satu permasalahan yang terus terjadi dan diturunkan dari generasi ke generasi. Disamping itu anak- 
anak menjadi korban kemiskinan terutama terbatasnya akses pendidikan dan pengetahuan yang seharusnya didapatkan oleh mereka. Padahal anak merupakan generasi penerus citacita perjuangan bangsa yang memiliki peran strategis dan mempunyai ciri dan sifat khusus yang menjamin kelangsungan eksistensi bangsa dan negara pada masa depan. Berdasarkan hal tersebut pendidikan merupakan hal dasar yang harus dimiliki oleh anak dan merupakan elemen yang sangat penting dan tidak boleh diabaikan dalam kehidupan.

Solusi utama dalam PKM ini yaitu pengadaan fasilitas baca dengan melaksanaan program literasi dengan membangun rumah baca RUBA MASUSA (Rumah Baca Masyarakat Suku Sambori) sebagai alternatif fasilitas pendidikan dengan tujuan agar masyarakat senantiasa dekat dengan buku dan terus belajar membaca demi memberantas buta aksara,kemiskinan, dan memberikan kesadaran masyarakat akan pentingnya literasi dalam berbagai aspek kehidupan.

Pendirian rumah baca ini diharapkan minat baca anak-anak dapat terfasilitasi dengan baik, masyarakat dan anak-anak memiliki pengetahuan yang lebih luas serta hak anak untuk memperoleh informasi dan ilmu pengetahuan dapat diwujudkan dengan baik oleh negara. Selain itu harapan jangka panjangnya adalah kualitas pendidikan dapat ditingkatkan sehingga perekonomian masyarakat dapat menjadi lebih baik dan buta aksara dapat ditekan.

\section{METODE ELAKSANAAN}

Solusi untuk memecahkan berbagai permasalahan dan untuk mengembangkan potensi minat baca dan sadar literasi anak-anak di Dusun Lengge, Desa Sambori, Kecematan Lambitu adalah sebagai berikut: Pertama, melakukan pemberdayaan secara berkala dan berkelanjutan terhadap masyarakat khususnya orang tua agar memiliki wawasan dan pengetahuan yang baik akan pentingnya pendidikan bagi anak-anaknya dan pentingnya pemenuhan hak anak. Kedua, mewadahi minat baca yang tinggi dari masyarakat khususnya anak-anak melalui pendirian RUBAMASUSA yang bersifat edukatif dan bebas biaya serta bebas diakses oleh siapapun. Ketiga, memberikan akses terhadap hak pendidikan bagi anak-anak di Dusun Lengge, Desa Sambori, Kecematan Lambitu melalui pendidikan non formal yakni RUBAMASUSA untuk mempersiapkan generasi penerus bangsa yang mempunyai kesadaran yang tinggi terhadap pendidikan dan sadar literasi. Keempat, memberikan wawasan dan penyadaran bagi masyarakat untuk keluar dari garis kemiskinan melalui pendidikan dan mengurangi angka putus sekolah sehingga anak-anak di Dusun Lengge, memiliki bekal pendidikan yang cukup dan dapat menekan angka kemiskinan melalui pendidikan.

Cara yang dapat ditempuh untuk mengatasi masalah tersebut ialah dengan mendirikan Rumah Baca yang menyediakan buku-buku bersifat edukatif bagi anak-anak, sebagai bentuk perwujudan terhadap hak anak untuk memperoleh pendidikan dan informasi guna pengembangan bakat dan minatnya. Selain itu Rumah Baca ini diharapkan dapat memberikan wawasan dan pengetahuan kepada orang tua yang mempunyai tanggung jawab secara langsung kepada anak-anaknya untuk memberikan pendidikan yang memadai sebagai bekal menuju masa depan.

Metode yang digunakan adalah dengan mendirikan secara langsung Rumah Baca yang dapat diakses oleh anak-anak secara gratis dan mudah sehingga anak-anak dapat secara bebas mendapatkan informasi bersifat edukatif, dapat mengekspresikan bakat dan minatnya serta potensi minat baca anak-anak yang tinggi dapat tersalurkan dengan baik. Selain itu dalam pengabdian ini akan dilakukan evaluasi dan pemberdayaan yang dilakukan secara berkala dan terus menerus. Dengan pemberdayaan yang dilakukan secara berkala dan terus menerus maka diharapkan konsistensi anak-anak untuk mencintai budaya membaca akan terus terjaga dan tujuan serta luaran yang diharapkan dapat diwujudkan dengan baik. Merealisasikan target 
dan luaran dari Program Pengabdian Masyarakat bagi Dosen dalam bentuk pendirian Rumah Baca sebagai perwujudan hak pendidikan bagi anak-anak di Dusun Lengge.

Realisasi dari program ini adalah tim pengabdi bersama dengan kepala desa telah komitmen untuk bekerjasama untuk mendirikan Rumah Baca serta melakukan pemantauan terhadap perkembangan dari Rumah Baca tersebut. Dalam Rumah Baca ini akan disediakan buku-buku bacaan yang bersifat edukatif seperti buku pelajaran, buku cerita, motivasi, dongeng, kesenian dan buku-buku lain yang dapat mendorong kreativitas anak berkembang.

Pengabdi juga akan melakukan kerjasama dengan berbagai pihak di desa tersebut seperti pemuda di Dusun Lengge, aparat pemerintah desa serta tokoh masyarakat secara umum. Kerjasama tersebut bertujuan untuk memaksimalkan keberadaan RUBAMASUSA, membantu operasional RUBAMASUSA secara berkelanjutan, membantu memonitoring dan menilai keberhasilan dari program ini.

Evaluasi dalam program pengabdian ini akan dilaksanakan secara rutin. Evaluasi akan dilakukan secara intern tim pengabdi dan jika dirasa perlu tim pengabdi akan melibatkan mitra, masyarakat dan anak-anak untuk memberikan saran terhadap program pengabdian ini. Dengan evaluasi tersebut maka diharapkan tim pengabdi dapat memberikan kontribusi dan pengabdian secara optimal serta tujuan dari Program Pengabdian kepada Masyarakat bagi Dosen ini dapat diwujudkan dengan baik.

\section{HASIL DAN PEMBAHASAN}

Kegiatan pembentukan RUBAMASUSA di Dusun Lengge, Desa Sambori Kecamatan Lambitu, oleh Tim Pengabdian ini dapat menjadi sebuah wujud pemenuhan hak pendidikan bagi anak-anak. Salah satu aspek yang mendasari masih belum terwujudnya kemudahan bagi anak untuk mengakses hak pendidikanya, rendahnya kesadaran masyarakat akan pentingnya pendidikan dan minimnya pengetahuan masyarakat serta tidak tersedianya akses informasi ataupun fasilitas informasi bagi anak-anak di Dusun Lengge, Desa Sambori Kecamatan Lambitu. Padahal hak pendidikan bagi anak merupakan hak yang mutlak sebagai bagian dari Hak Asasi Manusia dan tergolong sebagai non derogable rights sebagaimana tersirat dalam UUD 1945. Namun, tidak jarang anak-anak di penjuru Indonesia tidak mendapatkan hak pendidikan karna terbatasnya akses masyarakat terhadap ekonomi ataupun pendidikan.

Pembentukan RUBAMASUSA di dusun Lengge bagi anak ini diharapkan dapat menjadi wujud pemenuhan hak bagi anak sehingga akses masyarakat khususnya di Dusun Lengge, Desa Sambori Kecamatan Lambitu dapat terbuka. Kegiatan pengabdian ini memiliki tujuan untuk memberikan solusi pada mayarakat dalam memberantas buta aksaara, memenuhi hak pendidikan bagi anak yang terabaikan, sehingga anak-anak di Dusun Lengge dapat mengakses pendidikan dengan mudah selain dari pendidikan formal yang telah ditempuh dan akhirnya kesadaran masyarakat akan pentingnya pendidikan akan mulai masyarakat ini merupakan langkah solutif atas kurangnya akses pendidikan bagi anak di Dusun Lengge serta salah satu upaya untuk memberikan pengetahuan, pemahaman, dan penyadaran bagi masyarakat, khususnya bagi warga di Dusun Lengge terhadap pentingnya pendidikan sejak dini melalui Rumah Baca.

Berikut merupakan tahapan-tahapan yang telah dilaksanakan oleh tim pengabdi sesuai jadwal kegiatan yang diajukan sebelumnya:

Tabel 1.Tahapan Pelakasanaan/Jadwal Faktual Pelaksanaan

\begin{tabular}{|c|c|c|c|c|}
\hline \multirow[t]{2}{*}{ No } & \multirow{2}{*}{ Kegiatan } & \multicolumn{3}{|c|}{ Bulan ke- } \\
\hline & & 1 & 2 & 3 \\
\hline \multicolumn{5}{|c|}{ Sosialisasi } \\
\hline 1. & $\begin{array}{l}\text { Sosialisasi terhadap } \\
\text { kepala desa } \\
\text { Sambori dan kepala } \\
\text { sekolah SDN } \\
\text { Inpres Sambori }\end{array}$ & $\sqrt{ }$ & & \\
\hline
\end{tabular}




\begin{tabular}{|c|c|c|c|c|}
\hline 2. & $\begin{array}{l}\text { Sosialisasi } \\
\text { pentingnya literasi } \\
\text { dalam kehidupan } \\
\text { dikalangan orang } \\
\text { tua }\end{array}$ & $\sqrt{ }$ & & \\
\hline \multicolumn{5}{|c|}{ Persiapan } \\
\hline 3. & $\begin{array}{l}\text { Menentukan } \\
\text { tempat mendirikan } \\
\text { rumah baca }\end{array}$ & & $\sqrt{ }$ & \\
\hline 4. & $\begin{array}{l}\text { Merancang } \\
\text { kegiatan rutin dan } \\
\text { kegiatan unggulan } \\
\text { di rumah baca }\end{array}$ & & $\sqrt{ }$ & \\
\hline 5. & $\begin{array}{l}\text { Merekrut relawan } \\
\text { para profesional } \\
\text { dibidangnya } \\
\text { masing-masing }\end{array}$ & & $\sqrt{ }$ & \\
\hline 6. & $\begin{array}{l}\text { Menyediakan mata } \\
\text { lomba (mewarnai) } \\
\text { untuk } \\
\text { meningkatkan } \\
\text { minat baca siswa }\end{array}$ & & $\sqrt{ }$ & \\
\hline \multicolumn{5}{|c|}{ Pelaksanaan } \\
\hline 7. & $\begin{array}{l}\text { Melakukan } \\
\text { peresmian } \\
\text { pembukaan rumah } \\
\text { baca } \\
\text { (RUBAMASUSA) }\end{array}$ & & & $\sqrt{ }$ \\
\hline 8. & $\begin{array}{l}\text { Melakukan donasi } \\
\text { buku di } \\
\text { RUBAMASUSA } \\
\text { sebanyak } 300 \\
\text { eksemplar }\end{array}$ & & & $\sqrt{1}$ \\
\hline 9. & $\begin{array}{l}\text { Membuat daftar } \\
\text { hadir, Stempel } \\
\text { Perpustakaan }\end{array}$ & & & $\sqrt{ }$ \\
\hline 10. & $\begin{array}{l}\text { Melaksanakan } \\
\text { program unggulan } \\
\text { Ekspedisi Literasi } \\
\text { Puncak Lambitu } \\
\text { (ES LIPUT) }\end{array}$ & & & $\sqrt{ }$ \\
\hline 11. & $\begin{array}{l}\text { Melaksanakan } \\
\text { lomba mewarnai di } \\
\text { SDN Inpres } \\
\text { Sambori }\end{array}$ & & & $\sqrt{ }$ \\
\hline 12. & $\begin{array}{l}\text { Mengurus } \\
\text { perizinan resmi }\end{array}$ & & & $\sqrt{ }$ \\
\hline
\end{tabular}

\begin{tabular}{|c|l|l|l|c|}
\hline & $\begin{array}{l}\text { operasional rumah } \\
\text { baca }\end{array}$ & & \\
\hline \multicolumn{4}{|c|}{ Evaluasi } \\
\hline 13. & Evaluasi program & & & $\sqrt{ }$ \\
\hline 14. & $\begin{array}{l}\text { Pembuatan laporan } \\
\text { akhir }\end{array}$ & & $\sqrt{ }$ \\
\hline 15. & $\begin{array}{l}\text { Menyusun artikel } \\
\text { sebagai luaran }\end{array}$ & & & $\sqrt{ }$ \\
\hline
\end{tabular}

1. Kegiatan tahap Persiapan

Sosialisasi,survey tempat, melakukan sosialisasi untuk memberikan informasi awal kepada masyarakat suku sambori untuk mendapatkan dukungan melalui koordinasi dengan Kepala desa Sambori dan kepala sekolah SDN Inpres Sambori dalam mensosialisasikan program sadar literasi dan Rumah baca masyarakat.

Persiapan bertujuan untuk mengindetifikasi dan menyiapkan segala kebutuhan untuk pelaksanaan kegiatan, kegiatan persiapan dilakukan secara bersama dengan melibatkan kepala desa, kepala sekolah dan relawan para profesional dibidangnya masing-masing, serta menentukan tempat mendirikan rumah baca, melaksanakan kegiatan penunjang rumah baca (ESLIPUT), dan kegiatan rutin dan unggulan yang dilakukan di rumah baca.

Tim pengabdi mempersiapkan segala alat penunjang pembentukan taman baca pada tahap ini, dengan menyusun time schedule yang lebih rinci mengacu pada jadwal kegiatan dalam usulan proposal. Alat penunjang rumah baca dipersiapkan pada tahap ini, seperti pembelian buku, almari buku, karpet, dan lain-lain dilaksanakan pada bulan sebtember 2019 sampai dengan bulan Februari 2020.

2. Kegiatan Inti (pembentukan RUBAMASUSA)

Tahap pembentukan RUBAMASUSA dilaksanakan dengan membawa seluruh alat penunjang yang telah disiapkan oleh tim pengabdi ke lokasi pengabdian yaitu Dusun Lengge Desa Sambori Kecematan Lambitu. Tepatnya pada tanggal 3 September 2019 tim 
pengabdi membawa seluruh alat ke lokasi sekaligus penyusunan tata letak Rumah Baca, dalam pembentukan rumah baca harapnnya dapat memberikan dampak positif yaitu rasa kepemilikan bersama terhadap RUBAMASUSA.

Acara Sosialisasi atau Grand Opening Taman Baca dilaksanakan secara seremonial sebagai tanda dibukanya RUBAMASUSA. Penamaan RUBAMASUSA ini diinisiatori oleh Tim Pengabdi bersama Kepala Desa dan perangkat desa yang mengharapkan anak-anak Dusun Lengge kelak dapat menjadi orangorang sukses yang dapat membangun Dusun Lengge pada khususnya. Acara pembukaan dihadiri oleh Kepala Desa Sambori dan aparat desa lain, Kepala Dusun Lengge, Ketua RT 001/003 dan 002/003 serta relawan-relawan pendidikan. Kesadaran masyarakat mengenai pentingnya pendidikan untuk anak juga diharapkan akan tumbuh disampaikannya oleh Tim Pengabdi pada saat pembukaan taman baca.

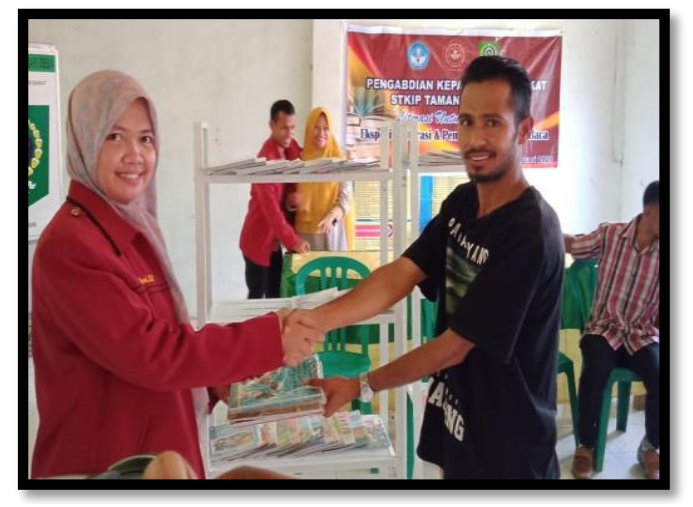

Gambar 1 Serah terima buku

Pembukaan rumah baca ditandai dengan penyerahan buku sebanyak 300 eksemplar dan mengurus perizinan resmi operasional rumah baca (RUBAMSUSA) pada perpustakaan daerah Kabupaten Bima dengan tujuan untuk mendapatkan izin resmi operasional dan mendapatkan donasi dana dan buku setiap bulan.
Tabel 2 Rekapan koleksi Rumah Baca

(Rubamasusa )hinga bulan Februari 2020

\begin{tabular}{|c|c|c|c|}
\hline No & Jenis Koleksi & Jumlah & Sumber \\
\hline 1 & Buku Calistung & 28 & membeli \\
\hline 2 & Buku agama & 10 & Sumbangan \\
\hline 3 & $\begin{array}{l}\text { Buku pertanian } \\
\text { dan } \\
\text { perternakan }\end{array}$ & 12 & Sumbangan \\
\hline 4 & $\begin{array}{l}\text { Buku } \\
\text { pengetahuan } \\
\text { umum }\end{array}$ & 69 & membeli \\
\hline 5 & Majalah anak & 73 & membeli \\
\hline 6 & $\begin{array}{l}\text { Cerpen dan } \\
\text { puisi }\end{array}$ & 84 & membeli \\
\hline 7 & Cerita Rakyat & 20 & membeli \\
\hline 8 & $\begin{array}{l}\text { Buku } \\
\text { IKreativitas } \\
\text { anak }\end{array}$ & 12 & Membeli \\
\hline 9 & $\begin{array}{ll}\text { Kamus } & 3 \\
\text { Bahasa } & \\
\end{array}$ & 8 & Sumbangan \\
\hline 10 & $\begin{array}{l}\text { Qur'an dan } \\
\text { Kunci Ibadah }\end{array}$ & 15 & Sumbangan \\
\hline 11 & $\begin{array}{l}\text { Buku big book } \\
\text { dan puzzle }\end{array}$ & 14 & Membeli \\
\hline \multicolumn{2}{|c|}{ Jumlah } & \multicolumn{2}{|c|}{345 eksemplar buku } \\
\hline
\end{tabular}

Berdasarkan rekapan koleksi rumah baca di atas bersumber dari hibah pengabdian masyarakat yang di danai oleh STKIP Taman Siswa Bima sebanyak 300 eksemplar dengan jenis buku buku calistung, buku pengetahuan umum, majalah anak, cerpen dan puisi, buku big book dan puzzle. sisanya bersumber dari sumbangan Perpustakan daerah kabupaten Bima yang diserahkan sejumlah 45 eksemplar, total keseluruhan buku yang tersedia di RUBAMASUSA sebanyak 345 eksemplar.

Setelah pembukaan, RUBAMSUSA mulai beroperasi dengan membukanya lebarlebar untuk anak-anak dan masyarakat Dusun Lengge setiap hari. RUBAMASUSA dibentuk dengan tujuan sebagai alternatif fasilitas pendidikan dengan tujuan agar masyarakat senantiasa dekat dengan buku dan terus belajar membaca demi memberantas buta aksara,memberikan kesadaran masyarakat akan pentingnya 
literasi dalam berbagai aspek kehidupan.Kegiatan literasi dalam menujang tujuan berdirinya RUBA MASUSA dibentuk kegiatan rutin dan kegitan unggulan.

Tabel 2 Program Rutin dan Program Unggulan RUBA MASUSA

\begin{tabular}{|c|c|c|}
\hline No & Uraian Kegiatan & Keterangan \\
\hline \multicolumn{3}{|c|}{ Program Rutin } \\
\hline 1 & $\begin{array}{l}\text { Membaca } 15 \text { menit } \\
\text { setiap hari }\end{array}$ & $\begin{array}{lr}\text { Senin } & \mathrm{s} / \mathrm{d} \\
\text { kamis } & 07.00- \\
07.15 & \end{array}$ \\
\hline 2 & \begin{tabular}{lr}
\multicolumn{2}{l}{ Pendampingan } \\
membaca & untuk \\
semua & lapisan \\
masyarakat &
\end{tabular} & $\begin{array}{l}\text { Selasa dan } \\
\text { rabu } \\
15.00-16.00\end{array}$ \\
\hline
\end{tabular}

\begin{tabular}{|l|lr|}
\hline \multicolumn{4}{|c|}{ Program unggulan } \\
\hline 3 & Esliput & 2x setahun \\
\hline 4 & $\begin{array}{l}\text { Pegadaan lomba } \\
\text { literasi }\end{array}$ & 2x setahun \\
\hline 5 & $\begin{array}{l}\text { Pengalangan Buku } \\
\text { secara berkala }\end{array}$ & 2 x setahun \\
\hline
\end{tabular}

Program rutin yang dilaksanakan di RUBA MASUSA dikoordinasi oleh salah satu guru honorer yang mengajar di SDN Inpres Sambori dan berdomisili di Dusun Lengge.

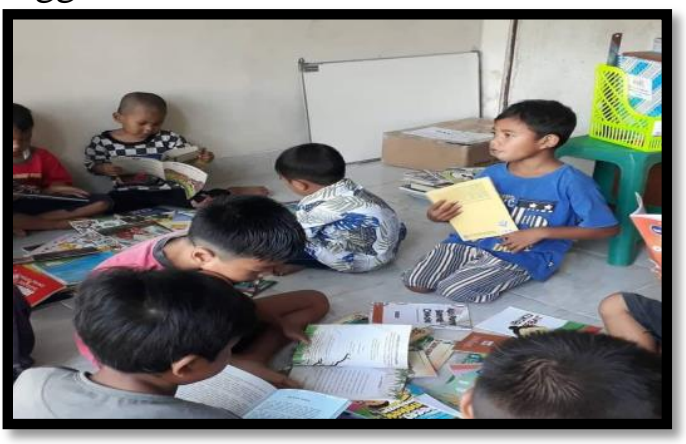

Gambar 2 Kegitan Rutin RUBA MASUSA

Untuk pelaksanaan program unggulan Tim Pengabdian terjun langsung kelapanangan untuk mengadakan lomba literasi dan melaksanakan Program ekspedisi literasi pucak lambitu (ES-Liput) program berkala yang mengajak dan melibatkan para profesional dari berbagai latar belakang profesi untuk memberikan motivasi dan inspirasi tentang literasi. Program ini mendukung program pengadaan rumah baca masyarakat suku sambori (RUBAMASUSA) agar secara langsung masyarakat dusun Lengge mendapatkan semangat untuk belajar membaca dan meningkatkan kemampuan literasinya, yang mana kemampuan literasi yang tinggi adalah kemampuan yang memungkinkan orang untuk membaca dunia bukan hanya kata, kalimat, paragraf, ataupun sebuah wacana.

Melalui program (ESLIPUT) siswa dan orang tua akan diberikan penyuluhan pentingnnya literasi. Program ini akan direkrut orang-orang yang sadar akan pentingnya pendidikan dari berbagai profesi untuk terjun langsung memberikan paparan berbagai profesi yang mereka geluti dan memberikan gambaran apa saja yang dilakukan dari profesi mereka, dengan upaya ini diharapkan siswa memiliki beragam citacita supaya mengurangi angka putus sekolah.

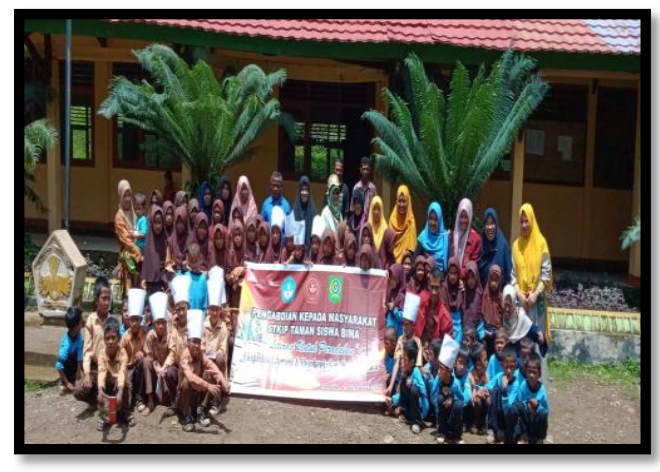

Gambar 3 Pelaksanaan Program ES-Liput berbagai Profesi Apoteker, Shef, dosen, Bidan, Fotografer, Pemadam Kebakaran.

Pembentukan Rumah Baca ini telah berhasil menarik perhatian anak-anak Dusun Lengge untuk menjadikan sebagai tempat untuk bermain sambil belajar. Hal tersebut dapat dilihat dari daftar hadir pengunjung yang cenderung konsisten. Bahan baca sebagai kebutuhan pendidikan anak, wajib dipenuhi karena masa kanak-kanak merupakan golden age, dimana rasa keingintahuan anak tinggi. Hadirnya RUBA MASUSA di tengah-tengah masyarakat dapat membentuk budaya yang baik. Anakanak dapat bermain sekaligus belajar dengan 
bahan bacaan yang positif. Tahap evaluasi yang berlangsung selama 7 minggu membuktikan bahwa kehadiran RUBA MASUSA memang sangat dibutuhkan terlihat dari antusiasme anak untuk mengunjungi taman baca.

Kehadiran anak-anak di RUBA MASUSA yang konsisten setiap harinya berarti bahwa anak-anak tidak bosan untuk datang berkali-kali. Selain bahan bacaan yang menarik, interaksi dengan teman-teman sebayanya juga memberikan atmosfir diskusi atas pengetahuan baru yang ia dapat dari bahan baca yang disediakan.

\section{KESIMPULAN}

Terselenggaranya program kemitraan masyarakat (PKM) yaitu pembentukan rumah baca masyarakat suku sambori (Rubamasusa) yang sudah memiliki koleksi buku sebanyak 345 berdasarkan rekapan bersumber dari hibah pengabdian masyarakat yang di danai oleh STKIP Taman Siswa Bima sebanyak 300 eksemplar dengan jenis buku buku calistung, buku pengetahuan umum, majalah anak, cerpen dan puisi, buku big book dan puzzle . sisanya bersumber dari sumbangan Perpustakan daerah kabupaten Bima yang diserahkan sejumlah 45 eksemplar, total keseluruhan buku yang tersedia di RUBAMASUSA sebanyak 345 eksemplar. Serta menerapkan beberapa kegiatan yang dapat meningkatkan pentingnya pendidikan dan sadar literasi baik itu kegitan rutin maupun kegitan unggulan. Program-program ini masyarakat dusun lengge sangat antusias ditandai dengan banyaknya masyarakat aik orang tua maupun anak-anak yang mengunjungi rumah baca.

\section{DAFTAR PUSTAKA}

Data Administrasi SDN Inpres Sambori 2019

Dokumentasi Data Administrasi Kantor Desa Sambori

Dokumentasi Data Administrasi Kecamatan Lambitu

Hasil Wawancara dengan Muhammad Said, S.Pd.SD, Kepala Sekolah SDN Inpres Sambori pada 20 November 2019 https://referensi.data.kemdikbud.go.id diakses tanggal 20 November 2019

Ihsan, Fuad, Dasar-DasarKependidikan, (Jakarta: Renika Cipta, 2011)

Observasi langsung di Desa Sambori 03 September 2019

Tety Nur Cholifah, I Nyoman Sudana Degeng "Pengaruh Latar Belakang Tingkat Pendidikan Orangtua Dan Gaya Belajar Terhadap Hasil Belajar Siswa", Jurnal Pendidikan Dasar Universitas Negeri Malang, EISSN: 2502-471X Volume: 1 Nomor: 3 Bulan Maret Tahun 2016.

Zulfitriani,"Pengaruh Latar Belakang Pendidikan Orang TuaTerhadap Prestasi Belajar Siswa SD", Jurnal Ilmiah PGSD (HOLISTIKA) Universitas Muhammadiyah Jakarta, (e-ISSN : 2614 - 8242) 